\title{
Transcriptional mechanisms for differential expression of outer membrane cytochrome genes omcA and mtrC in Shewanella oneidensis MR-1
}

\author{
Takuya Kasai ${ }^{1}$, Atsushi Kouzuma ${ }^{1 *}$, Hideaki Nojiri ${ }^{2}$ and Kazuya Watanabe ${ }^{1}$
}

\begin{abstract}
Background: Shewanella oneidensis MR-1 is capable of reducing extracellular electron acceptors, such as metals and electrodes, through the Mtr respiratory pathway, which consists of the outer membrane cytochromes OmcA and MtrC and associated proteins MtrA and MtrB. These proteins are encoded in the $m$ tr gene cluster (omcA-mtrCAB) in the MR-1 chromosome.
\end{abstract}

Results: Here, we investigated the transcriptional mechanisms for the mtr genes and demonstrated that omcA and $m t r C$ are transcribed from two upstream promoters, $P_{\text {omcA }}$ and $P_{m t r c}$, respectively. In vivo transcription and in vitro electrophoretic mobility shift assays revealed that a CAMP receptor protein (CRP) positively regulates the expression of the $m$ tr genes by binding to the upstream regions of $P_{\text {omca }}$ and $P_{m t r c}$. However, the expression of omcA and $m t r C$ was differentially regulated in response to culture conditions; specifically, the expression from $P_{m t r C}$ was higher under aerobic conditions than that under anaerobic conditions with fumarate as an electron acceptor, whereas expression from $\mathrm{P}_{\text {omca }}$ exhibited the opposite trend. Deletion of the region upstream of the CRP-binding site of $P_{\text {omca }}$ resulted in a significant increase in promoter activity under aerobic conditions, demonstrating that the deleted region is involved in the negative regulation of $\mathrm{P}_{\text {omc }}$.

Conclusions: Taken together, the present results indicate that transcription of the $m$ tr genes is regulated by multiple promoters and regulatory systems, including the CRP/CAMP-dependent regulatory system and yet-unidentified negative regulators.

Keywords: Extracellular electron transfer, Outer membrane cytochrome, Transcriptional regulation, Shewanella

\section{Background}

Shewanella species belong to the class Gammaproteobacteria and are widely distributed in nature, including marine and freshwater sediments [1,2]. A few members of this genus have attracted considerable attention due to their importance in the biogeochemical cycling of metals [3] and utility in biotechnology processes, such as bioremediation [4] and bioelectrochemical systems [5-7]. Shewanella species are able to respire a wide variety of organic and inorganic compounds, including oxygen, fumarate, nitrate, nitrite, thiosulfate, elemental sulfur, trimethylamine $\mathrm{N}$-oxide, dimethyl sulfoxide (DMSO), and anthraquinone-2,6-disulphonate, as well as both soluble

\footnotetext{
* Correspondence: akouzuma@toyaku.ac.jp

'School of Life Sciences, Tokyo University of Pharmacy and Life Sciences,

1432-1 Horinouchi, Hachioji 192-0392, Tokyo, Japan

Full list of author information is available at the end of the article
}

and solid metals, such as iron, manganese, uranium, chromium, cobalt, technetium, and vanadium [8-11]. This respiration electron acceptor plasticity implies that members of this genus have evolved flexible respiratory mechanisms in order to survive in redox-stratified environments, such as oxic/anoxic interfaces in sediments. Supporting this speculation, comparative genomic analysis among Gammaproteobacteria revealed that Shewanella have a relatively large number of signal-transduction proteins containing PAS domains, which are involved in the detection of various environmental signals, such as light, oxygen, and redox potential [12,13], suggesting that they have well-developed environment-sensing and regulatory systems. However, little is known about how Shewanella species regulate respiratory activity at the molecular level in response to changes in environmental conditions. 
S. oneidensis MR-1 is the most extensively studied strain of Shewanella because of its annotated genome sequence [14], ease of genetic manipulation [5], and capability to directly transfer electrons to extracellular substances, such as metal oxides and electrodes, without exogenously added mediator [15]. Five primary component proteins, CymA, MtrA, MtrB, MtrC, and OmcA, comprising the extracellular electron transfer (EET) pathway (the Mtr respiratory pathway) have been identified in strain MR-1 [16]. OmcA and MtrC are outer membrane cytochromes (OM-cyts) containing 10 hemebinding sites, and play key roles in transferring electrons to extracellular electron acceptors [17]. It has been proposed that MR-1 releases electron from these OM-cyts through both direct EET pathways, in which electrons are directly transferred from OM-cyts that attach to solid metals [18,19], and indirect EET pathways, in which electrons are transferred from OM-cyts to distant solid metals via secreted electron-shuttle compounds, such as flavins [20,21]. Although biochemical studies indicate that both MtrC and OmcA are able to transfer electrons to solid Fe(III) oxides [18,19], MtrC appears to play a dominant role in electron transfer to electrodes, whereas OmcA plays an greater role in attachment of cells to solid surfaces [22,23], indicating that functional differences exist between these two OM-cyts.

Despite extensive biochemical characterization of MtrC and OmcA, limited information is available on how MR-1 regulates these OM-cyt genes at the transcriptional level. In the MR-1 genome, four genes encoding the proteins comprising the Mtr respiratory pathway are organized in a cluster oriented in the same direction (Figure 1A). Previous studies of MR-1 have demonstrated that a cyclic AMP (cAMP) receptor protein (CRP) and adenylate cyclase (CyaC) responsible for cAMP production play key roles in transcriptional activation of the $m t r$ genes, as well as the anaerobic respiratory genes involved in nitrate, fumarate, and DMSO reduction [24,25]. Although these genes are up-regulated under anaerobic (oxygen-limited) and electrode-respiring conditions [26-30], the molecular mechanisms and signal transduction pathways underlying the cAMP/CRP-dependent transcriptional activation of the $m t r$ genes remain to be elucidated, as CRP does not contain PAS or other known redox-sensing domains. In addition, although two different transcription start sites (TSPs) have been identified in the upstream regions of $o m c A$ and $m t r C$ $[31,32]$, the regulatory mechanisms, including the role of CRP, in the transcription of the $m t r$ genes have not been determined.

In the present study, we investigated the regulatory mechanisms that control expression of the mtr genes, particularly focusing on regulatory differences between omcA and $m \operatorname{trC}$ and the involvement of CRP in the regulation of these genes. The findings presented here provide new insight into the complex regulatory mechanisms of the Mtr respiratory pathway in Shewanella.

\section{Results}

Transcriptional units of the mtr genes

Previous studies have identified two independent TSPs for the $m$ tr genes [31,32] (Figure 2). Beliaev et al. [31] detected a TSP located 119 bp upstream of the ATG start codon of $m$ trC $\left(\mathrm{TSP}_{m t r C}\right.$; Figure $\left.2 \mathrm{~B}\right)$ using $5^{\prime} \mathrm{RACE}$ PCR, and more recently, Shao et al. [32] identified a TSP located $93 \mathrm{bp}$ upstream of omcA (TSP ${ }_{\text {omc }}$; Figure 2A) among the total of 2,531 TSPs detected in S. oneidensis MR-1 using $5^{\prime}$-end RNA sequencing. Although these experiments were conducted using cells grown under aerobic [32] and unclear [31] conditions, the present 5 '-RACE PCR analysis detected the identical TSPs $\left(\mathrm{TSP}_{\text {omc }}\right.$ and $\left.\mathrm{TSP}_{m t r C}\right)$ in both aerobically grown cells and cells cultured anaerobically with $10 \mathrm{mM}$ fumarate. The presence of $\mathrm{TSP}_{m t r C}$ was also confirmed by primer extension analysis (Additional file 1: Figure S1). The 5' RACE PCR using the $m t r A$ - and $m t r B$-specific primers detected no TSPs other than $\mathrm{TSP}_{m t r C}$ (data not shown),
A

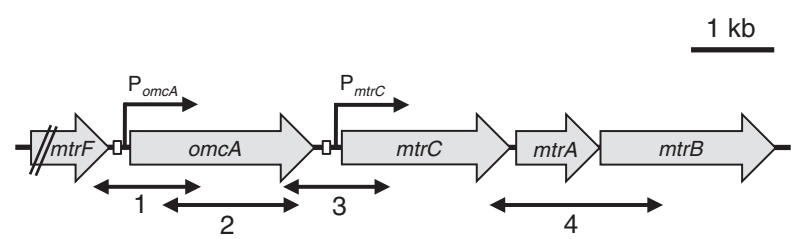

B

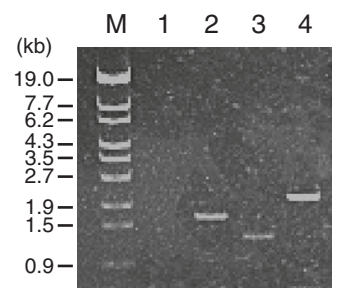

Figure 1 The organization and transcriptional units of the $\boldsymbol{m}$ tr genes. (A) Schematic illustration of the organization of the $m$ tr genes. Solid arrows indicate the location and direction of the transcriptional promoters upstream of omc $A\left(P_{\text {omcA }}\right)$ and $m$ tr $C\left(P_{m t r}\right)$. The bidirectional arrows indicate the target regions of the RT-PCR analysis. The open boxes indicate the CRP-binding regions identified by the EMSA analysis. (B) RT-PCR analysis of the $\mathrm{mtr}$ genes. WT cells were grown anaerobically in LM containing $10 \mathrm{mM}$ fumarate until the early stationary growth phase. The lane number corresponds to the target regions shown in panel $\mathbf{A}$. The molecular sizes (kb) of the marker (lane $\mathbf{M})$ are indicated to the left of the gel. 


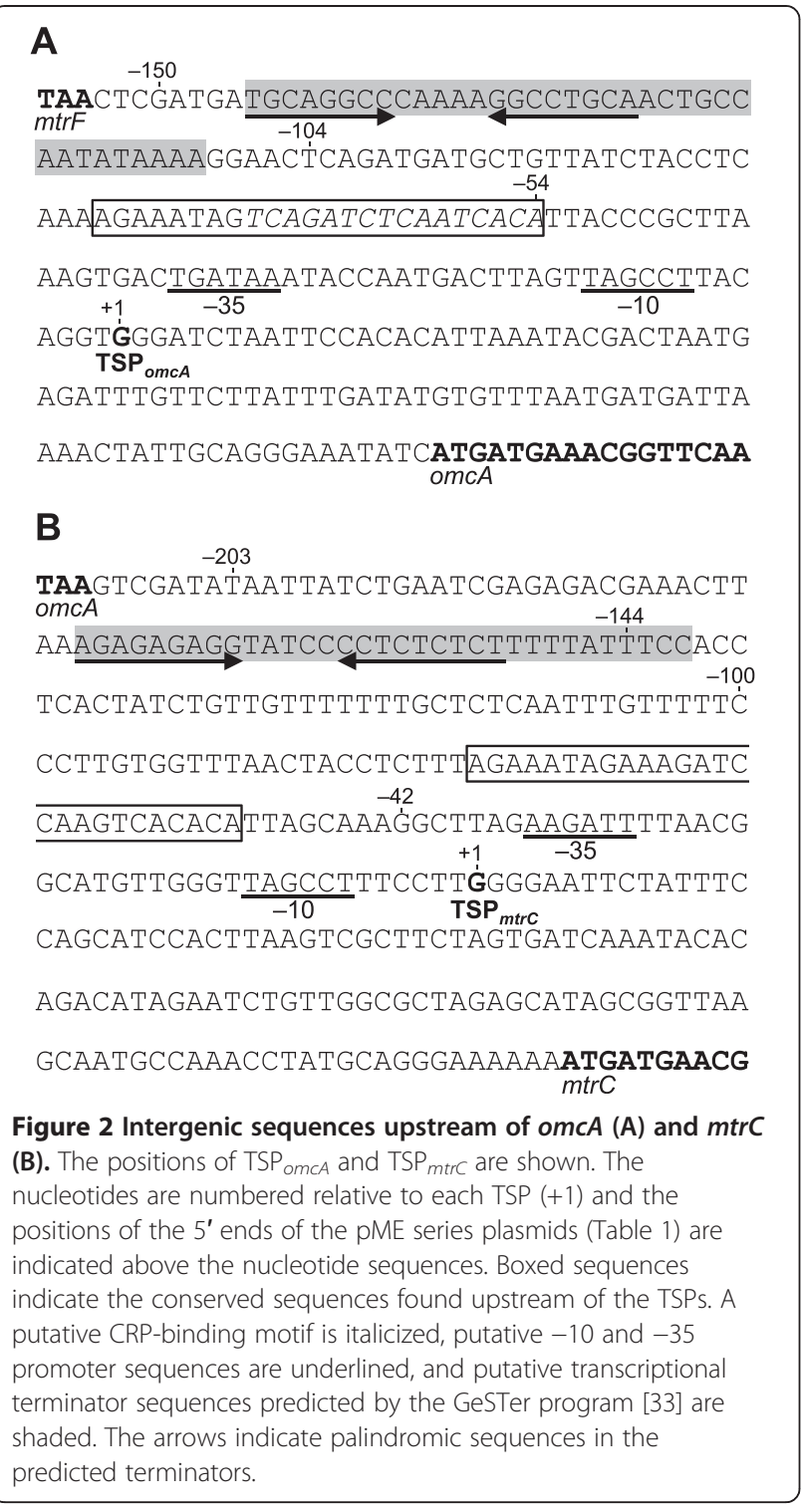

indicating that $m \operatorname{tr} C, m \operatorname{tr} A$, and $m \operatorname{tr} B$ were co-transcribed as an operon, as suggested by Beliaev et al. [31].

A common sequence (5'-TAGCCT-3') that was weakly similar to the Escherichia coli consensus -10 sequence (5'-TATAAT-3') was present upstream of TSP $_{\text {omca }}$ and $\mathrm{TSP}_{m t r C}$, although a consensus -35 sequence was not conclusively identified upstream of either gene (candidate sequences are shown in Figure 2). Notably, highly conserved sequences were found in the upstream regions of $\mathrm{TSP}_{\text {omcA }}$ (5'-AGAAATAGTCAGATCTCAATCACA-3'; position -77 to -54$)$ and TSP $_{m t r C}\left(5^{\prime}\right.$-AGAAATAGAAAGATCCAAGT $C A C A-3^{\prime}$; position -76 to -53 ; common nucleotides are italicized) (Figure 2). The former sequence contained a putative CRP-binding motif (5'-TCAGATCTCAATCAC A-3') [34] based on its similarity to the consensus sequence for CRP binding in E. coli (5'-TGTGA-N6-TCTCA-3')
[35-37], suggesting that CRP directly binds to the DNA region upstream of $\mathrm{TSP}_{\text {omcA }}$. However, the corresponding sequence in the upstream region of $\mathrm{TSP}_{m t r C}\left(5^{\prime}\right.$-AAAGATCCAAGTCACA-3') contained only half of the CRPbinding consensus sequence.

We also performed RT-PCR analysis to investigate the transcriptional units of the mtr gene cluster using total RNA extracted from MR-1 cells grown anaerobically with $10 \mathrm{mM}$ fumarate (Figure 1). No transcripts were detected when the intergenic region between $m t r F$ and omcA was analyzed (Figure 1B, lane 1), suggesting that the transcription of $m t r F$ is terminated by the putative terminator sequence downstream of $m \operatorname{trF}$ (Figure 2A) and does not affect the transcription of omcA. Although a terminator-like sequence was also predicted downstream of omcA (Figure 2B), a weak band was detected when the omcA-mtrC intergenic region was amplified (Figure 1B, lane 3), indicating that the transcription from $\mathrm{TSP}_{\text {omc }}$ is not completely terminated within this intergenic region. A transcript containing the $m t r C-m t r A$ and $m \operatorname{tr} A-m \operatorname{tr} B$ intergenic regions was also amplified (Figure 1B, lane 4), demonstrating the polycistronic transcription of these three genes.

\section{Differential expression of omcA and $m$ trC}

The identification of $\mathrm{TSP}_{o m c A}$ and $\mathrm{TSP}_{m t r C}$ suggested that $o m c A$ and $m \operatorname{tr} C$ (the $m \operatorname{tr} C A B$ operon) were regulated by different regulatory mechanisms, leading to different expression patterns. To test this hypothesis, MR-1 cells were grown aerobically and under anaerobic conditions with $10 \mathrm{mM}$ fumarate until the early stationary phase, and the expression levels of omcA and $m t r C$ were then determined by quantitative RT-PCR analysis (Figure 3). The expression level of omcA under anaerobic conditions was 2.3 -fold higher than that under aerobic conditions, whereas the expression level of $m t r C$ under anaerobic conditions was 2.7-fold lower than that under aerobic conditions. We also measured the expression levels of omcA and $m t r C$ in an in-frame $c r p$-deletion mutant $(\Delta c r p)$. When $\Delta c r p$ cells were grown under aerobic conditions $(\Delta c r p$ did not grow under fumaratereducing conditions), the expression levels of $o m c A$ and $m \operatorname{tr} C$ were markedly decreased as compared with wildtype MR-1 (WT) cells (Figure 3). Taken together, these results demonstrate that, although CRP is essential for the transcriptional activation of both omcA and $m t r C$, these genes are differently regulated in response to culture conditions.

To further characterize the expression patterns of $o m c A$ and $m t r C$, we constructed the $l a c Z$ reporter plasmids pMEomcA-150 and pMEmtrC-203 (Table 1), which contained nearly all of the intergenic regions upstream of omcA and $m t r C$, respectively (Figure 2), and compared the activity of promoters for omcA $\left(\mathrm{P}_{\text {omcA }}\right)$ 


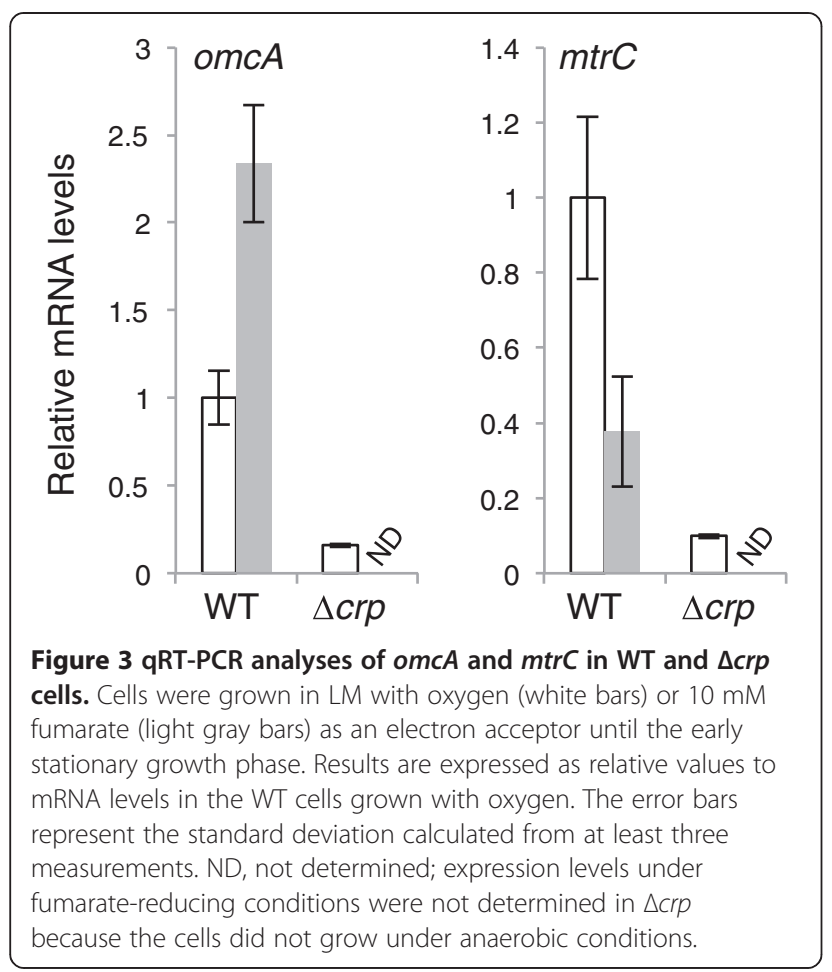

and $m \operatorname{trC}\left(\mathrm{P}_{m t r C}\right)$ in WT cells under several different growth conditions (Figure 4). In this experiment, 10 and $50 \mathrm{mM}$ fumarate were used for anaerobic cultivation to expose cells to electron acceptor- and electron donorlimited conditions, respectively (15 mM lactate was used as the electron donor), as it was reported that the electron donor to acceptor ratio affects the $c$-type cytochrome content and EET activities of MR-1 cells [38]. When cells were grown anaerobically with 10 and $50 \mathrm{mM}$ fumarate, similar patterns of lac $Z$ expression from $\mathrm{P}_{\text {omc }}$ (Figure 4A) and $\mathrm{P}_{m t r C}$ were observed (Figure 4B). Specifically, under $10 \mathrm{mM}$ fumarateadded conditions, the activities of both promoters were increased in the early stationary phase compared to those in the mid-logarithmic phase, whereas the opposite trend was observed under $50 \mathrm{mM}$ fumarateadded conditions. In contrast, under aerobic growth conditions, $\mathrm{P}_{m t r C}$ activity was highest in the early stationary phase (Figure 4B), whereas $\mathrm{P}_{\text {omca }}$ activity was only slightly elevated (Figure 4A). These results suggest that $\mathrm{P}_{\text {omca }}$ and $\mathrm{P}_{m t r C}$ exhibit differential transcriptional responses in the presence of oxygen, but respond similarly to changes in the ratios of electron donors and acceptors under anaerobic conditions. The ratios of the expression levels under aerobic and $10 \mathrm{mM}$ fumarate-added conditions were in good agreement with those observed in the qRT-PCR analysis (Figure 3), indicating that transcription from $\mathrm{P}_{\text {omcA }}$ does not significantly affect expression of the downstream $m \operatorname{tr} C A B$ operon in vivo. It is therefore likely that $o m c A$ transcription is largely attenuated due to the putative terminator sequence downstream of omcA (Figure 2B).

\section{Upstream regulatory regions of $\mathrm{P}_{\text {omcA }}$ and $\mathrm{P}_{\text {mtrc }}$}

To determine the DNA regions involved in the transcriptional regulation of omcA and $m t r C$, we performed 5 '-deletion analysis of the sequences upstream of $\mathrm{TSP}_{\text {omcA }}$ and $\mathrm{TSP}_{m t r C}$ in the reporter plasmids pMEomcA-150 and pMEmtrC-203 (Table 1). MR-1 strains harboring the reporter plasmids with promoter region deletions were grown aerobically or anaerobically with $10 \mathrm{mM}$ fumarate until the early stationary phase, and LacZ activities were then measured and compared (Figure 5). Under aerobic growth conditions, the LacZ activity of cells transformed with pMEomcA-104, in which the DNA region from -150 to -105 relative to $\mathrm{TSP}_{\text {omc }}$ was deleted, was increased to a comparable level to that in anaerobically grown cells (Figure 5A), suggesting the deleted DNA region was involved in the negative regulation of $\mathrm{P}_{\text {omcA }}$ under aerobic conditions. The LacZ activities of cells transformed with pMEomcA-54 under both aerobic and anaerobic conditions were decreased to the same level as those of pMElacZ (vector control), demonstrating that the region from -104 to -55 relative to $\mathrm{TSP}_{\text {omc }}$, which contained the conserved upstream sequence and putative CRP-binding site (Figure 2A), was essential for the activation of $\mathrm{P}_{\text {omcA }}$.

In the $5^{\prime}$-deletion analysis of the sequence upstream of $\mathrm{TSP}_{m t r C}$ (Figure 5B), stepwise increases of LacZ activities were observed under both aerobic and anaerobic conditions when the DNA regions from -203 to -145 and from -144 and to -101 were deleted. However, the LacZ activities in the aerobically grown cells were consistently higher than those found in the anaerobically cultured cells. This finding suggests that the DNA region from -203 to -101 relative to $\mathrm{TSP}_{m t r} \mathrm{C}$ contains sequences that constitutively repress the activity of $\mathrm{P}_{\text {mtrC. }}$. As only low levels of LacZ activity was detected in cells harboring pMEmtrC-42, the region from -100 to -41 , which also contained the conserved sequence upstream of TSP omcA $_{\text {and }}$ TSP ${ }_{m t r C}$ (Figure 2B), was required for the activation of $\mathrm{P}_{m t r C}$.

\section{Direct activation of $\mathrm{P}_{\text {omcA }}$ and $\mathrm{P}_{\text {mtr }}$ by CRP}

To investigate the involvement of CRP in the activation of $\mathrm{P}_{\text {omcA }}$ and $\mathrm{P}_{m t r C}$, we measured the LacZ activities of $\Delta c r p$ cells transformed with the $5^{\prime}$-deletion reporter plasmids (Figure 5). No significant LacZ activity was detected for any of the reporter plasmids in $\Delta c r p$ cells grown aerobically, demonstrating that CRP was essential for the activation of both $\mathrm{P}_{\text {omc }}$ and $\mathrm{P}_{m t r C}$. We also performed electrophoretic mobility shift assays (EMSA) to investigate whether CRP directly binds to the regions 
Table 1 Bacterial strains and plasmids used in this study

\begin{tabular}{|c|c|c|}
\hline Strain or plasmid & Relevant characteristic & Source or reference \\
\hline \multicolumn{3}{|l|}{ Bacterial strains } \\
\hline \multicolumn{3}{|l|}{ Escherichia coli } \\
\hline JM109 & $\begin{array}{l}\text { Host for cloning; recA1. endAl, gyrA96, thi. hsdR17, supE44, relA1, } \\
\lambda-, \triangle\left(\text { lac-proAB), [F,' traD36, proAB, lacl' }{ }^{9} Z \triangle M 15\right]\end{array}$ & [39] \\
\hline JM109入pir & Host for cloning pSMV10; JM109 lysogenized with $\lambda$ pir & {$[40]$} \\
\hline WM6026 & $\begin{array}{l}\text { Donor strain for conjugation; lacl9, rrnB3, DElacZ4787, hsdR514, } \\
\text { DE(araBAD)567, E(rhaBAD)568, rph-1, att-lambda::pAE12-del(oriR6K-cat:frt5), } \\
\text { DE(endA)::frt, uidA(delMlu)::pir(wt), attHK::pJK1006-del1/2 (deloriR6K-cat::frt5, } \\
\text { deltrfA::frt) }\end{array}$ & William Metcalf, University of Illinois \\
\hline BL21 (DE3) & 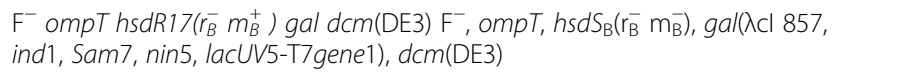 & Novagen \\
\hline \multicolumn{3}{|c|}{ Shewanella oneidensis } \\
\hline MR-1 & Wild type & ATCC [2] \\
\hline$\Delta c r p$ & The crp gene (SO_0624) disrupted & This study \\
\hline \multicolumn{3}{|l|}{ Plasmids } \\
\hline pMElacZ & pME4510 derivative, lac $Z \mathrm{Gm}^{\mathrm{r}}$ & {$[41]$} \\
\hline pMEomcA-54 & pMElacZ containing the region from -54 to +93 relative to $\mathrm{TSP}_{\text {omcA }}$ & This study \\
\hline pMEomcA-104 & pMElacZ containing the region from -104 to +93 relative to TSP omcA & This study \\
\hline pMEomcA-150 & pMElacZ containing the region from -150 to +93 relative to TSP omcA & This study \\
\hline pMEmtrC-42 & pMElacZ containing the region from -42 to +119 relative to $\mathrm{TSP}_{m+r} \mathrm{C}$ & This study \\
\hline pMEmtrC-100 & pMElacZ containing the region from -100 to +119 relative to $\mathrm{TSP}_{m+r} \mathrm{C}$ & This study \\
\hline pMEmtrC-144 & pMElacZ containing the region from -144 to +119 relative to $\operatorname{TSP}_{m+r}$ & This study \\
\hline pMEmtrC-203 & pMElacZ containing the region from -203 to +119 relative to $\mathrm{TSP}_{\text {mtr }}$ & This study \\
\hline pSMV10 & $9.1 \mathrm{~kb}$ mobilizable suicide vector; oriR6K, mobRP4, sacB, $\mathrm{Km}^{r}, \mathrm{Gm}^{\mathrm{r}}$ & $\begin{array}{l}\text { Chad Saltikov, California Institute } \\
\text { of Technology }\end{array}$ \\
\hline pSMV-0624 & $1.5 \mathrm{~kb}$ fusion PCR fragment containing $\triangle \mathrm{crp}$ cloned into the Spel site of pSMV10 & This study \\
\hline pET-28(a) & Expression vector, $\mathrm{T} 7$ promoter & Novagen \\
\hline pET-crp & pET-28(a) containing N-ht-crp & This study \\
\hline
\end{tabular}

upstream of $o m c A$ and $m t r C$ (Figure 6). When a labeled DNA probe containing the region from -87 to -35 relative to $\mathrm{TSP}_{\text {omc }}$ (PBomcA1; Figure 6A) was incubated with purified CRP protein, shifted bands corresponding to CRP-DNA complexes were observed in a cAMPdependent manner (Figure 6B). However, no shifted bands were detected when a probe containing the region from -50 to +13 relative to $\mathrm{TSP}_{\text {omc }}$ (PBomcA2) was used (Figure 6B), demonstrating that the sequence between -87 to -50 , which contained the conserved upstream sequence and putative CRP-binding site (Figure 2), was required for the specific binding of CRP to the upstream region of $\mathrm{TSP}_{o m c}$. In EMSA performed with probes containing upstream regions of $m t r C$ (PBmtrC1 [-143 to +117] and PBmtrC2 [-4 to +117]; Figure 6A), cAMP-dependent shifted bands were observed with $\mathrm{PBmtrC} 1$, but not with $\mathrm{PBmtrC} 2$, demonstrating that CRP can bind to the region from -143 to -4 relative to $\mathrm{TSP}_{m t r C}$ (Figure $6 \mathrm{~B}$ ). The weaker intensities of the shifted bands observed with PBmtrC1 compared with those with PBomcA1 are likely attributable to the lack of an obvious CRP-binding motif upstream of $\mathrm{TSP}_{m t r C}$ (Figure 2B). Taken together, these results indicate that $\mathrm{CRP}$ directly binds to the upstream regions of $\mathrm{TSP}_{\text {omc }}$ and $\mathrm{TSP}_{m t r C}$, and up-regulates the transcription of the corresponding genes.

\section{Discussion}

In this study, we demonstrated that two independent transcriptional promoters, $\mathrm{P}_{o m c A}$ and $\mathrm{P}_{m t r C}$, differentially regulate the expression of $o m c A$ and $m t r C$, although both promoters require CRP for transcriptional activation. CRP is a global transcriptional regulator that plays a key role in regulating carbon metabolism in enteric bacteria $[42,43]$. In Shewanella, evidence suggests that CRP is involved in the regulation of anaerobic respiration $[24,25,44]$. For instance, the cAMP/CRP-dependent regulatory system was reported to be essential for regulating anaerobic arsenate reduction in Shewanella sp. strain ANA-3 [43]. CRP appears to be required for transcriptional 

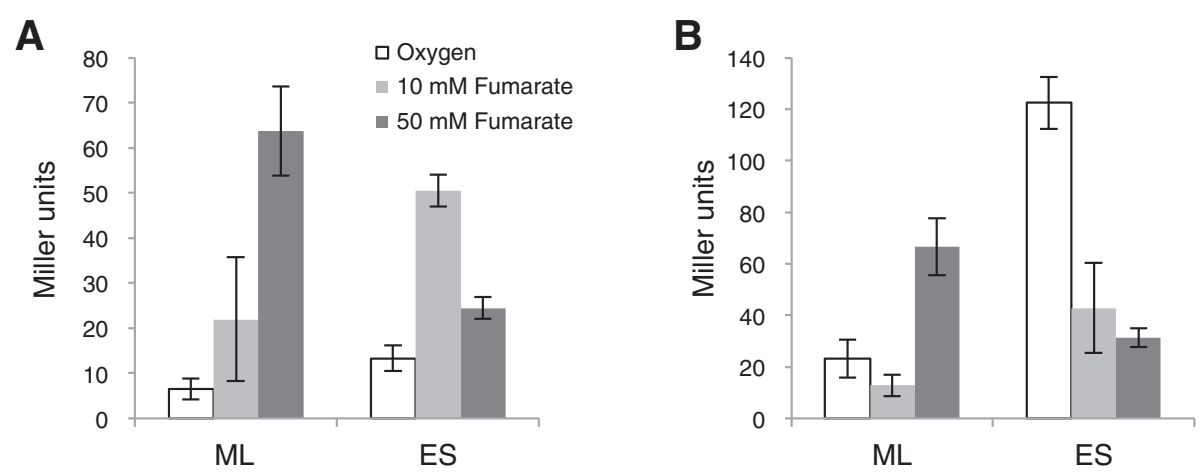

Figure 4 LacZ expression from $\mathbf{P}_{\text {omc }}(\mathbf{A})$ and $\mathbf{P}_{\text {mtrc }}$ (B). WT cells harboring pMEomcA-150 or pMEmtrC-203 were grown with oxygen (white bars), $10 \mathrm{mM}$ fumarate (light gray bars) or $50 \mathrm{mM}$ fumarate (dark gray bars) as the electron acceptor, and their LacZ activities were measured in the mid-logarithmic (ML) and early stationary (ES) growth phases. The error bars represent the standard deviation calculated from at least three measurements. The LacZ activity in WT cells harboring pMElacZ (control vector) was below 3 Miller units under all of the tested conditions (data not shown).

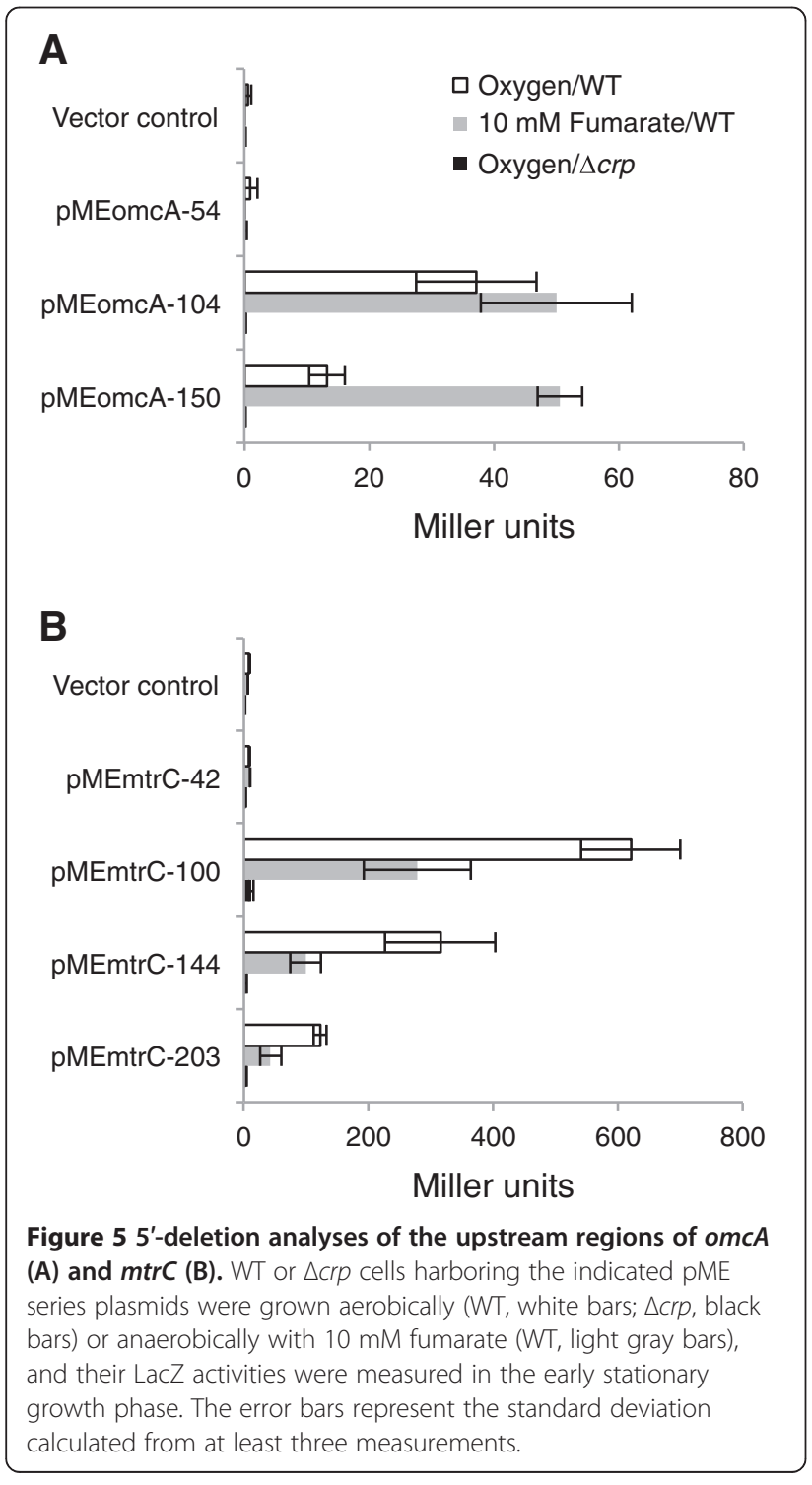

activation of the genes involved in the reduction of $\mathrm{Fe}(\mathrm{III})$, $\mathrm{Mn}(\mathrm{IV})$, fumarate, nitrate, and DMSO in S. oneidensis MR-1, as a crp-deletion mutant of this strain exhibited decreased ability to reduce these electron acceptors [24]. Consistent with this finding, markedly reduced expression of several anaerobic respiratory genes $(m t r, f c c A$, nap, and $d m s$ ) were also observed in crp knockout mutants of MR-1 [25,45], although it remains unclear whether CRP directly or indirectly regulates these genes. In the present study, we confirmed that the expression from $\mathrm{P}_{\text {omca }}$ and $\mathrm{P}_{m t r C}$ was markedly decreased in a crp-deletion mutant $(\Delta c r p)$ by qRT-PCR and LacZ reporter analyses (Figures 3 and 5). In addition, EMSA experiments revealed that CRP directly binds to the regions upstream of $o m c A$ and $m \operatorname{tr} C$ (Figure 6), demonstrating that the CRP/cAMP-dependent regulatory system directly activates both $\mathrm{P}_{\text {omcA }}$ and $\mathrm{P}_{\text {mtrC. }}$. Taken together with the results of the $5^{\prime}$-deletion analysis (Figure 5), it is likely that the conserved sequences found upstream of $\mathrm{TSP}_{\text {omca }}$ and $\mathrm{TSP}_{m t r C}$ (Figure 2) are critical for CRP binding and transcriptional initiation at these TSPs.

The mechanisms underlying the CRP/cAMP-dependent regulatory system have been extensively studied in $E$. coli K-12. When complexed with cAMP, CRP binds to a target DNA sequence, resulting principally in the transcriptional activation of the downstream gene [36,46]. The cAMPCRP complex binds as a dimer to the consensus sequence $5^{\prime}$-TGTGA-N6-TCACAA-3', which is typically found in the flanking regions ( -35 and -10 sequences) of associated core promoters, and activates transcription by interacting directly with RNA polymerase [36,46-48]. Although CRPdependent promoters exhibit great structural diversity, they are classified based on the position of the central base of the CRP-binding site [36]. The putative CRP-binding site upstream of TSP $_{\text {omc }}$ (5'-TCAGATCTCAATCACA-3') and the corresponding site in the conserved sequence upstream of TSP $_{m t r C}\left(5^{\prime}\right.$-AAAGATCCAAGTCACA-3') are 

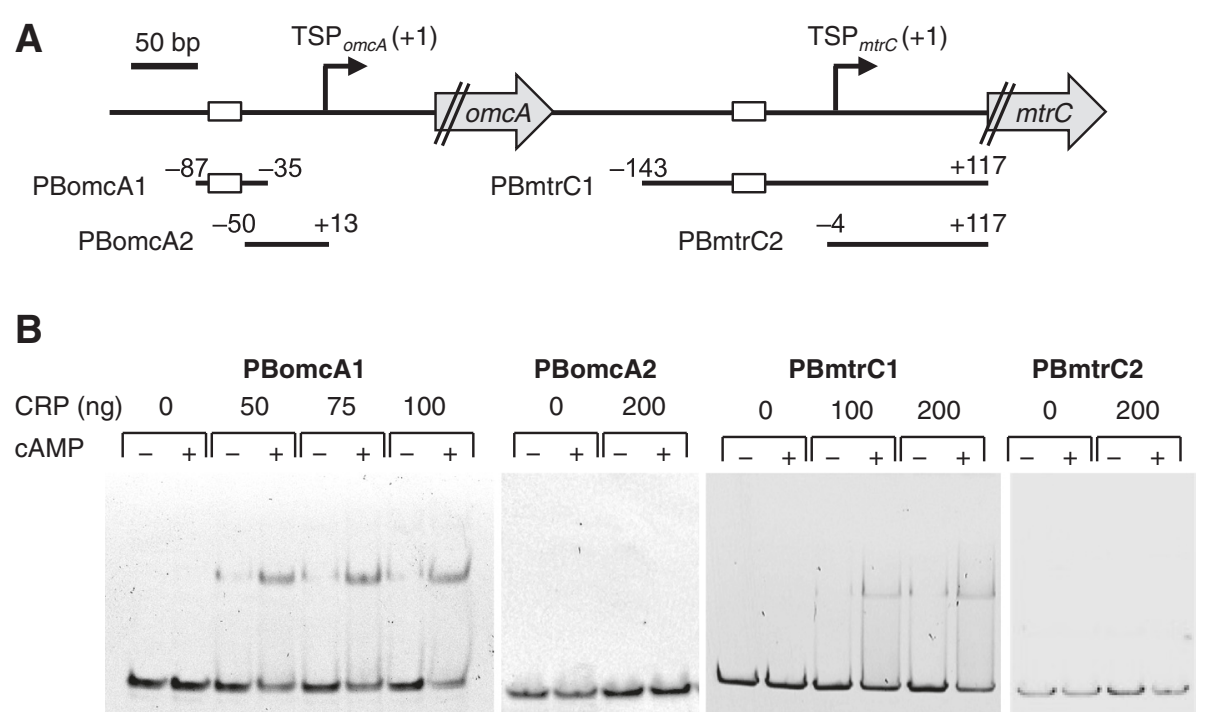

Figure 6 Binding of CRP to the upstream regions of omcA and mtrC by EMSA. (A) DNA fragments used as probes are indicated with bars. The positions of the $5^{\prime}$ and $3^{\prime}$ ends of the fragments relative to $\operatorname{TSP}_{\text {omcA }}$ or $\operatorname{TSP}_{m+r}(+1)$ are shown. The open boxes indicate the consensus regions upstream of TSP omcA or TSP mtrc shown in Figure 2. (B) Binding of CRP to each probe in the presence (+) or absence (-) of cAMP. The probes were generated by PCR and labeled with Cy3 at the $5^{\prime}$ termini. The quantities of CRP are indicated above.

centered at -61.5 and -60.5 relative to the respective TSPs, positions that closely correspond to those of the CRPbinding sites for class I CRP-dependent promoters (-61.5) [49,50]. Although $\mathrm{P}_{\text {omcA }}$ and $\mathrm{P}_{m t r C}$ lack a typical -35 sequence, it is known that -35 sequences are poorly conserved in most CPR-dependent promoters, whereas their -10 regions show relatively high similarity to the consensus sequence $[36,51]$. It is therefore conceivable that the cAMP-CRP complex in S. oneidensis activates transcription at $\mathrm{P}_{\text {omc }}$ and $\mathrm{P}_{m t r C}$ in a similar manner to the wellcharacterized mechanism in E. coli, although the CRP target sequences appear to differ between these bacteria. A previous study reported that the addition of cAMP to aerobic cultures of MR-1 resulted in significant induction of fumarate reductase activity [24], suggesting that intracellular cAMP concentration is a key determinant of the ability of MR-1 cells to reduce anaerobic electron acceptors. However, although E. coli cells grown under fermentation or anaerobic respiration conditions produce more cAMP than cells grown under aerobic conditions [52], it is currently unknown how intracellular cAMP concentrations are regulated in Shewanella. Further investigation is therefore needed to elucidate the signal transduction mechanisms underlying the CRP/cAMP-dependent activation of $\mathrm{P}_{\text {omcA }}$ and $\mathrm{P}_{m t r C}$.

Similar transcriptional responses were observed for $\mathrm{P}_{\text {omc }}$ and $\mathrm{P}_{m t r C}$ when cells were grown under fumaratereducing conditions (Figure 4). However, the transcriptional activities of these promoters were dependent on the concentration of fumarate in the culture medium, suggesting that the balance of electron donors and acceptors strongly influences the activities of $\mathrm{P}_{\text {omcA }}$ and $\mathrm{P}_{m t r C}$. In medium supplemented with $10 \mathrm{mM}$ fumarate, cells experience electron acceptor limitation during the stationary growth phase, because the fumarate is completely oxidized by the $15 \mathrm{mM}$ lactate in the growth medium. The increased activities of $\mathrm{P}_{\text {omc }}$ and $\mathrm{P}_{m t r C}$ under these conditions (Figure 4) suggest that the $m t r$ genes are up-regulated in response to electron acceptorlimiting conditions. In contrast, when cells were grown with excess electron acceptor (50 $\mathrm{mM}$ fumarate), the activities of $\mathrm{P}_{\text {omc }}$ and $\mathrm{P}_{m t r C}$ were decreased in the early stationary phase, suggesting that the $m t r$ genes are down-regulated following the depletion of electron donors under anaerobic conditions. These notions are supported by the previous observation that MR-1 shows higher reduction activity toward an extracellular substance (azo dye) when grown in continuous culture under electron acceptor-limited conditions compared to electron donor-limited conditions [38]. It is therefore conceivable that the ratio of electron acceptors to electron donors influences intracellular redox status, such as the redox states of the $\mathrm{NAD}(\mathrm{H})$ and quinone pools [53], resulting in the altered expression of the $m t r$ genes. However, in mid-logarithmic phase, the activities of $\mathrm{P}_{\text {omc }}$ and $\mathrm{P}_{m t r C}$ in cultures containing $50 \mathrm{mM}$ fumarate were higher than those in cultures supplemented with $10 \mathrm{mM}$ (Figure 4). Although the reason for this difference is not clear, it is possible that other factors, such as cell density, determine the transcriptional activities of $\mathrm{P}_{\text {omcA }}$ and $\mathrm{P}_{m t r C}$ in the logarithmic growth phase, in which sufficient electron donors and acceptors are readily available. 
The transcriptional activities of $\mathrm{P}_{\text {omc }}$ and $\mathrm{P}_{m t r C}$ differed in the presence of oxygen (Figures 3 and 4). Although the $m t r$ genes exhibit increased expression under anaerobic conditions compared with aerobic cultures $[27,28]$, here, we found that cells grown under aerobic conditions until the early stationary phase displayed markedly higher transcriptional activity of $\mathrm{P}_{m t r C}$ compared to that observed under fumarate-reducing conditions (Figure 4B). In the mid-logarithmic phase, however, the activity of $\mathrm{P}_{m t r C}$ in the presence of oxygen was lower than that in anaerobic cultures supplemented with $50 \mathrm{mM}$ fumarate, but was slightly higher than that under the $10 \mathrm{mM}$ fumarate-added condition, indicating that the ratios of aerobic and anaerobic expression from $\mathrm{P}_{m t r C}$ are strongly influenced by the growth phase and anaerobic electron acceptor concentration. In contrast, the activity of $\mathrm{P}_{\text {omc }}$ was maintained at lower levels than that of $\mathrm{P}_{m t r C}$ under aerobic conditions (Figure 4A), demonstrating a clear difference in the regulation of $\mathrm{P}_{\text {omca }}$ and $\mathrm{P}_{m t r C}$. This finding suggests that although $\mathrm{P}_{\text {omcA }}$ and $\mathrm{P}_{m t r C}$ are both dependent on CRP, additional mechanisms are also likely involved in the regulation of these promoters. Notably, the activity of $\mathrm{P}_{\text {omcA }}$ in aerobically grown cells was increased by deleting the DNA region from -150 to -104 relative to $\mathrm{TSP}_{\text {omc }}$, suggesting that this region is involved in the negative regulation of $\mathrm{P}_{o m c A}$. In E. coli, the CytR regulator acts as a transcriptional repressor for several CRP-dependent promoters, including deoP2, by binding to an operator region located upstream of a CRP-binding site (CRP-1) through protein-protein interactions with the CAMPCRP complex, resulting in transcriptional repression $[54,55]$. Therefore, it is possible that under aerobic conditions, an unknown regulator binds to the upstream region of $\mathrm{P}_{o m c A}$ and represses the transcription of $o m c A$.

5 '-deletion analysis demonstrated that deletion of the DNA regions upstream of $\mathrm{P}_{m t r C}$ significantly increased the activity of this promoter under both aerobic and anaerobic conditions. Although the reason for this increase remains unclear, it is possible that a non-specific repressor, such as a homolog of E. coli H-NS [56], which binds preferentially to AT-rich DNA sequences, binds to the upstream region of $\mathrm{P}_{m t r C}$ and constitutively represses expression from this promoter. This speculation is supported by the fact that positions -203 to -101 relative to $\mathrm{TSP}_{\text {mtrC }}$ have a very low GC content, and that relationships between $\mathrm{H}$-NS and CRP-dependent promoters have been found in $E$. coli $[57,58]$.

\section{Conclusions}

The results of the present study indicate that transcription of the $m$ tr genes is regulated by the CRP/cAMP-dependent regulatory system and yet-unidentified negative regulatory mechanisms, suggesting that Shewanella exploit multiple signal transduction pathways to control EET activity in response to environmental conditions and intracellular energy status. The differential expression of $o m c A$ and $m t r C$ under aerobic conditions (Figure 4) indicates that redoxsensing regulators, such as PAS domain-containing proteins, are involved in the expression of these OM-cyt genes, thereby tuning the composition of the OM-cyts to the environment. As the expression of $m t r C$ under aerobic conditions was markedly up-regulated in the early stationary phase, growth phase-dependent regulatory mechanisms might also be involved in $m t r$ gene transcription. Further studies are needed to elucidate the molecular mechanisms underlying the regulatory differences between $\mathrm{P}_{\text {omc }}$ and $\mathrm{P}_{m t r C}$, and to explore the functional relationship between the OM-cyts of Shewanella.

\section{Methods}

\section{Bacterial strains, plasmids, and growth conditions}

The bacterial strains and plasmids used in this study are listed in Table 1. E. coli strains were routinely cultured in Luria-Bertani (LB) medium or $2 \times$ yeast extracttryptone $(2 \times \mathrm{YT})$ medium at $37^{\circ} \mathrm{C}$. E. coli mating strain (WM6026) required 2,6-diaminopimelic acid (DAP) at $100 \mu \mathrm{g} / \mathrm{mL}$ for growth. S. oneidensis strains were cultured at $30^{\circ} \mathrm{C}$ in $\mathrm{LB}$ medium or modified lactate medium (LM) comprised of $15 \mathrm{mM}$ lactate, $9 \mathrm{mM}\left(\mathrm{NH}_{4}\right)_{2} \mathrm{SO}_{4}$, $5.7 \mathrm{mM} \mathrm{K} \mathrm{HPO}_{4}, 3.3 \mathrm{mM} \mathrm{KH_{2 }} \mathrm{PO}_{4}, 5.0 \mathrm{~g} / \mathrm{L}$ yeast extract, and $30 \mathrm{mM}$ HEPES-NaOH buffer ( $\mathrm{pH}$ 7.4). LM was supplemented with yeast extract to supply cells with abundant nutrients, other than electron donors and acceptors. The optical density at $600 \mathrm{~nm}\left(\mathrm{OD}_{600}\right)$ of the cultures was measured using a DU800 spectrophotometer (Beckman). For aerobic cultivation, S. oneidensis strains were inoculated in 300-mL baffled Erlenmeyer flasks containing $100 \mathrm{~mL}$ LM, and were cultivated with shaking on a rotary shaker at $180 \mathrm{rpm}$ until the middle logarithmic or early stationary growth phase $\left(\mathrm{OD}_{600} 0.5\right.$ to 0.7 , or $>2.0$, respectively). Fumarate was used as a model anaerobic electron acceptor in this study because it is known that $S$. oneidensis MR-1 requires CRP to reduce both solid metals and fumarate [24], and exhibits similar transcriptional responses when exposed to metal and non-metal anaerobic electron acceptors [27]. For anaerobic cultivation under electron acceptor-limited conditions, S. oneidensis strains were inoculated in 100$\mathrm{mL}$ bottles containing $80 \mathrm{~mL}$ LM supplemented with $10 \mathrm{mM}$ fumarate, and were cultured until the middle logarithmic or early stationary growth phase $\left(\mathrm{OD}_{600}\right.$ of 0.08 to 0.1 , or $>0.25$, respectively). For anaerobic cultivation under electron donor-limited conditions, S. oneidensis strains were cultured in LM supplemented with $50 \mathrm{mM}$ fumarate until the middle logarithmic or early stationary growth phase $\left(\mathrm{OD}_{600}\right.$ of 0.2 to 0.4 or $>0.7$, 
respectively). The bottles containing the anaerobic cultures were capped with Teflon-coated butyl rubber septum, sealed with aluminum crimp seals, and purged with pure nitrogen gas. When necessary, $100 \mu \mathrm{g} / \mathrm{mL}$ ampicillin, $15 \mu \mathrm{g} / \mathrm{mL}$ gentamicin $(\mathrm{Gm})$, or $50 \mu \mathrm{g} / \mathrm{mL}$ kanamycin $(\mathrm{Km})$ was added to the culture medium. Agar plates contained 1.5\% Bacto agar (Difco).

\section{RNA extraction}

Shewanella cells were grown aerobically in LM or anaerobically in LM containing $10 \mathrm{mM}$ fumarate, and were harvested at early stationary growth phase. RNA was extracted from cells using Trizol reagent (Invitrogen) following the manufacturer's instructions and was purified using an RNeasy Mini Kit and RNase-Free DNase Set (Qiagen). The quality of extracted RNA was evaluated using an Agilent 2100 Bioanalyzer with RNA 6000 Pico reagents and RNA Pico Chips (Agilent Technologies) according to the manufacturer's instructions.

\section{RT-PCR}

For cDNA synthesis, $1.0 \mu \mathrm{g}$ total RNA extracted from anaerobically grown MR-1 cells was subjected to a reverse transcription (RT) reaction using Superscript III Reverse Transcriptase (Invitrogen) and Random Primers (Invitrogen) following the manufacturer's instructions. The cDNA was amplified with Ex Taq DNA polymerase (TaKaRa) and the primer sets listed in Additional file 2: Table S1. Amplification conditions were as follows: an initial denaturation of $95^{\circ} \mathrm{C}$ for $30 \mathrm{~s}$, followed by 25-30 amplification cycles consisting of $95^{\circ} \mathrm{C}$ for $30 \mathrm{~s}, 55^{\circ} \mathrm{C}$ for $30 \mathrm{~s}$ and $72^{\circ} \mathrm{C}$ for $30 \mathrm{~s}$, and a final elongation at $72^{\circ} \mathrm{C}$ for $7 \mathrm{~min}$. Negative control reactions without reverse transcriptase were also performed.

\section{Determination of transcription start points}

$5^{\prime}$-Rapid amplification of cDNA ends (5'-RACE) PCR reactions were performed using $1.0 \mu \mathrm{g}$ total RNA extracted from anaerobically grown MR-1 cells and a SMATer RACE cDNA Amplification Kit (Clontech) following the manufacturer's instructions. The first-strand cDNA was synthesized using the gene-specific primer omcA_RACE_out or mtrC_RACE_out (Additional file 2: Table S1) and subsequently amplified using Universal Primer A Mix (Clontech) and the nested primer omcA_RACE_in or mtrC_RACE_in (Additional file 2: Table S1). The amplified fragments were analyzed by agarose gel electrophoresis and purified using a QIAquick PCR purification kit (Qiagen). The purified fragments were cloned into T-Vector pMD19 (Takara) and sequenced to determine the $5^{\prime}$-end points.

Primer extension analysis was performed according to a previously described method with slight modifications [59]. Briefly, $10 \mu \mathrm{g}$ total RNA extracted from aerobically or anaerobically grown MR-1 cells was reversetranscribed using SuperScript III Reverse Transcriptase (Invitrogen) and an IR800-labeled primer (Aloka), PEmtrC-100 (Additional file 2: Table S1). The primer extension products were purified by phenol-chloroform extraction and ethanol precipitation, and were then subjected to electrophoresis using a Li-Cor 4200 Automated DNA Sequencer (Li-Cor) together with the sequence reaction products generated with the same primer.

\section{qRT-PCR}

Quantitative RT-PCR (qRT-PCR) was performed using a LightCycler 1.5 instrument (Roche) according to a method described previously [60-62]. The PCR mixture $(20 \mu \mathrm{L})$ contained $15 \mathrm{ng}$ total RNA, $1.3 \mu \mathrm{L}$ of $50 \mathrm{mM}$ $\mathrm{Mn}(\mathrm{OAc})_{2}$ solution, $7.5 \mu \mathrm{L}$ LightCycler RNA Master SYBR Green I (Roche), and $0.15 \mu \mathrm{M}$ of the primers listed in Additional file 2: Table S1. To generate standard curves, DNA fragments of target genes (mtrC, omcA, and the 16S rRNA gene) were PCR amplified from the total DNA of strain MR-1, and were then purified by agarose gel electrophoresis using a QIAEX II Gel Extraction Kit (Qiagen) following the manufacturer's instructions. A dilution series of the purified products from each reaction and the original RNA samples were used as template for quantitative PCR analysis. Specificity of the quantitative PCR was verified by dissociation-curve analysis. The expression levels of the target genes $(m t r C$ and $o m c A$ ) were normalized based on the expression level of the reference gene (16S rRNA gene). All measurements were performed in triplicate at a minimum.

\section{Gene disruption}

The in-frame disruption of the crp gene in strain MR-1 was performed using a two-step homologous recombination method with suicide plasmid pSMV-10, as described previously [63-65]. Briefly, a 1.6-kb fusion product, consisting of upstream (746 bp) and downstream (724 bp) sequences of the crp gene joined by an 18-bp linker sequence, was constructed by PCR and in-vitro extension using the primers listed in Additional file 2: Table S1. The amplified fusion product was ligated into the SpeI site of pSMV-10, generating pSMV-crp, which was then introduced into MR-1 by filter mating with E. coli WM6026. Transconjugants (single-crossover clones) were selected on LB plates containing $\mathrm{Km}$ and were further cultivated for $20 \mathrm{~h}$ in LB medium lacking antibiotics. The cultures were then spread onto LB plates containing $10 \%(\mathrm{w} / \mathrm{v})$ sucrose to isolate $\mathrm{Km}$-sensitive doublecrossover mutants. Disruption of the crp gene in the obtained strains was confirmed by PCR. One representative mutant strain in which the crp gene was disrupted in-frame was selected and designated $\Delta c r p$. 


\section{$\beta$-Galactosidase reporter assay}

To construct a series of $\mathrm{P}_{\text {omcA }}$-lac $Z$ transcriptional fusion plasmids (Table 1), the regions upstream of $o m c A$ were amplified from total DNA of MR-1 using a series of forward primers (omcA_F-54 through omcA_F-150) and a reverse primer, omcA_R + 93. To construct a series of $\mathrm{P}_{m t r C}-l a c Z$ transcriptional fusion plasmids (Table 1), a series of forward primes (mtrC_F-42 through mtrC_F-203) and a reverse primer, $m t r C \_R+117$, were used. PCR products were digested with EcoRI and HindIII, or BamHI and HindIII (restriction endonuclease sites incorporated into the primer sequences; see Additional file 2: Table S1), and the fragments were cloned between the corresponding sites of pMElacZ [41]. Positive clones were verified by DNA sequencing. The constructed reporter plasmids were introduced into wild-type MR-1 or $\Delta c r p$ by electroporation according to a method described elsewhere [66]. The resultant reporter strains were aerobically or anaerobically grown in LM as described above. $\beta$-Galactosidase activity was measured in triplicate at a minimum according to the method of Miller [67].

\section{CRP protein purification}

To construct a plasmid expressing N-terminally histidinetagged CRP (N-ht-CRP) protein, the crp gene was amplified from total DNA of MR-1 with primers crp_NdeI_F and crp_BamHI_R (Additional file 2: Table S1). The obtained PCR products were digested with NdeI and BamHI, and cloned between the corresponding sites of the expression vector $\mathrm{pET}-28 \mathrm{a}(+)$ (Novagen), which contains an N-terminal histidine tag sequence. The resultant plasmid, pET-N-ht-crp (Table 1), was introduced into E. coli BL21(DE3). Cells carrying the plasmid were grown in 300-mL baffled Erlenmeyer flasks containing $100 \mathrm{~mL} 2 \times$ YT medium supplemented with $\mathrm{Km}$ at $30^{\circ} \mathrm{C}$. Isopropyl-1-thio- $\beta$-D-galactopyranoside (IPTG) was added to a final concentration of $0.1 \mathrm{mM}$ when the $\mathrm{OD}_{600}$ reached 0.5 to 0.8 . After further cultivation for $3 \mathrm{~h}$, the cells were harvested by centrifugation, washed with IMAC wash buffer (Bio-Nobile), and suspended in $3.0 \mathrm{~mL}$ of the same buffer. The cell suspension was subjected to ultrasonication with a Misonix S4000 Sonicator (Misonix). The cell extract was centrifuged at $1000 \times g$ for $5 \mathrm{~min}$ to remove cell debris. Nht-CRP contained in the supernatant was purified using a QuickPick IMAC Metal Affinity Kit for Proteins (Bio-Nobile) following the manufacturer's instructions. The protein samples eluted by the QuickPick IMAC system were analyzed by sodium dodecyl sulfate-polyacrylamide gel electrophoresis (SDS-PAGE) and stored at $4^{\circ} \mathrm{C}$ until use (within $12 \mathrm{~h}$ ). The protein concentration was determined using a Micro BCA Protein Assay Kit (Pierce).

\section{EMSA}

Cy3-labeled DNA probes were generated by PCR with the Cy3-labeled primer sets listed in Additional file 2: Table S1. PCR products were analyzed by nondenaturing polyacrylamide gel electrophoresis and then purified using a QIAEX II Gel extraction Kit (Qiagen) following the manufacturer's instructions. An electrophoretic mobility shift assay (EMSA) was performed as previously described, but with slight modifications [41]. DNA-binding reactions were performed in a $20-\mu \mathrm{L}$ reaction mixture containing $10 \mathrm{mM}$ Tris- $\mathrm{HCl}(\mathrm{pH} 7.6)$, $0.5 \mathrm{mM}$ disodium EDTA ( $\mathrm{pH} 8.0$ ), $100 \mathrm{mM} \mathrm{KCl,} 50 \mu \mathrm{g}$ / $\mathrm{mL}$ bovine serum albumin, $50 \mu \mathrm{g} / \mathrm{mL}$ poly (deoxyinosinic-deoxycytidilic) acid [poly(dI-dC); Sigma-Aldrich], $50 \mu \mathrm{M}$ cAMP, 10\% (v/v) glycerol, $2 \mathrm{nM}$ Cy3-labeled DNA probe, and 0 to $200 \mathrm{ng}$ of purified N-ht-CRP. The mixture was incubated on ice for $30 \mathrm{~min}$ and then loaded onto a non-denaturing $12.5 \%$ polyacrylamide gel. Electrophoresis was conducted at $150 \mathrm{~V}$ in $0.5 \times$ Trisborate-EDTA (TBE) buffer. Fluorescent gel images were obtained using a Typhoon FLA 9000 (GE Healthcare).

\section{Additional files}

Additional file 1: Figure S1. Determination of the transcription start point (TSP) upstream of $m t r C$ by primer extension. The arrow indicates the primer extension product generated using equal amounts of total RNA from wild-type (WT) cells grown aerobically (lane 1) or anaerobically with $10 \mathrm{mM}$ fumarate (lane 2). Lanes T, A, G, and C correspond to the sequence ladders generated with the same primer as the primer extension products; the sequence pattern is shown to the right of the gel.

Additional file 2: Table S1. Primers used in this study.

\section{Abbreviations}

CRP: CAMP receptor protein; DMSO: Dimethyl sulfoxide; EET: Extracellular electron transfer; OM-cyt: Outer-membrane cytochrome; TSP: Transcription start site; RACE: Rapid amplification of cDNA ends; WT: Wild-type; EMSA: Electrophoretic mobility shift assay; DAP: 2,6-diaminopimelic acid; LM: Lactate medium; N-ht-CRP: N-terminally histidine-tagged CRP.

Competing interests

The authors declare that they have no competing interests.

\section{Authors' contributions}

TK carried out the majority of the experimental work and drafted the manuscript. AK conceived of the study, participated in its design and coordination, and drafted the manuscript. HN contributed in providing experimental equipment and editing the manuscript. KW supervised the study and performed manuscript editing. All authors read and approved the final manuscript.

\section{Acknowledgements}

This work was supported by JSPS KAKENHI Grant Numbers 24880030 and 26850056. We thank Dr. Koji Miyamoto and Dr. Yurika Takahashi for technical advice.

\section{Author details}

${ }^{1}$ School of Life Sciences, Tokyo University of Pharmacy and Life Sciences, 1432-1 Horinouchi, Hachioji 192-0392, Tokyo, Japan. ${ }^{2}$ Biotechnology Research Center, The University of Tokyo, 1-1-1 Yayoi, Bunkyo-ku 113-8657, Tokyo, Japan. 
Received: 27 November 2014 Accepted: 11 March 2015 Published online: 21 March 2015

\section{References}

1. Myers $\mathrm{CR}$, Nealson $\mathrm{KH}$. Bacterial manganese reduction and growth with manganese oxide as the sole electron acceptor. Science. 1988;240:1319-21.

2. Venkateswaran $K$, Moser DP, Dollhopf ME, Lies DP, Saffarini DA, MacGregor BJ, et al. Polyphasic taxonomy of the genus Shewanella and description of Shewanella oneidensis sp. nov. Int J Syst Bacteriol. 1999;49:705-24.

3. Flynn TM, O'Loughlin EJ, Mishra B, DiChristina TJ, Kemner KM. Sulfur-mediated electron shuttling during bacterial iron reduction. Science. 2014;344:1039-42.

4. Hau HH, Gralnick JA. Ecology and biotechnology of the genus Shewanella. Annu Rev Microbiol. 2007;61:237-58.

5. Sydow A, Krieg T, Mayer F, Schrader J, Holtmann D. Electroactive bacteria-molecular mechanisms and genetic tools. Appl Microbiol Biotechnol. 2014;98:8481-95.

6. Ross DE, Flynn JM, Baron DB, Gralnick JA, Bond DR. Towards electrosynthesis in Shewanella: energetics of reversing the Mtr pathway for reductive metabolism. PLoS One. 2011;6:e16649.

7. Flynn JM, Ross DE, Hunt KA, Bond DR, Gralnick JA. Enabling unbalanced fermentations by using engineered electrode-interfaced bacteria. mBio. 2010;1:1-8.

8. Nealson $\mathrm{KH}$, Saffarini D. Iron and manganese in anaerobic respiration: environmental significance, physiology, and regulation. Annu Rev Microbiol. 1994;48:311-43.

9. Liu C, Gorby YA, Zachara JM, Fredrickson JK, Brown CF. Reduction kinetics of $\mathrm{Fe}(\mathrm{III}), \mathrm{Co}(\mathrm{III}), \mathrm{U}(\mathrm{VI}), \mathrm{Cr}(\mathrm{VI})$, and $\mathrm{TC}(\mathrm{VII})$ in cultures of dissimilatory metal-reducing bacteria. Biotechnol Bioeng. 2002;80:637-49.

10. Hau HH, Gilbert A, Coursolle D, Gralnick JA. Mechanism and consequences of anaerobic respiration of cobalt by Shewanella oneidensis strain MR-1. Appl Environ Microbiol. 2008;74:6880-6.

11. Carpentier W, Sandra K, De Smet I, Brigé A, De Smet L, Van Beeumen J. Microbial reduction and precipitation of vanadium by Shewanella oneidensis. Appl Environ Microbiol. 2003;69:3636-9.

12. Fredrickson JK, Romine MF, Beliaev AS, Auchtung JM, Driscoll ME, Gardner TS, et al. Towards environmental systems biology of Shewanella. Nat Rev Microbiol. 2008;6:592-603.

13. Taylor BL, Zhulin IB. PAS domains: internal sensors of oxygen, redox potential, and light. Microbiol Mol Biol Rev. 1999;63:479-506.

14. Heidelberg JF, Paulsen IT, Nelson KE, Gaidos EJ, Nelson WC, Read TD, et al. Genome sequence of the dissimilatory metal ion-reducing bacterium Shewanella oneidensis. Nat Biotechnol. 2002;20:1118-23.

15. Kim BH, Kim HJ, Hyun MS, Park DH. Direct electrode reaction of Fe(III)-reducing bacterium, Shewanella putrefaciens. J Microbiol Biotechnol. 1999;9:127-31.

16. Shi L, Squier TC, Zachara JM, Fredrickson JK. Respiration of metal (hydr)oxides by Shewanella and Geobacter: a key role for multihaem c-type cytochromes. Mol Microbiol. 2007;65:12-20.

17. Shi L, Chen B, Wang Z, Elias DA, Mayer MU, Gorby YA, et al. Isolation of a high-affinity functional protein complex between OmcA and MtrC: two outer membrane decaheme c-type cytochromes of Shewanella oneidensis MR-1. J Bacteriol. 2006;188:4705-14.

18. Lower BH, Shi L, Yongsunthon R, Droubay TC, McCready DE, Lower SK. Specific bonds between an iron oxide surface and outer membrane cytochromes MtrC and OmcA from Shewanella oneidensis MR-1. J Bacteriol. 2007;189:4944-52.

19. Xiong Y, Shi L, Chen B, Mayer MU, Lower BH, Londer Y, et al. High-affinity binding and direct electron transfer to solid metals by the Shewanella oneidensis MR-1 outer membrane c-type cytochrome OmcA. J Am Chem Soc. 2006;128:13978-9.

20. Marsili E, Baron DB, Shikhare ID, Coursolle D, Gralnick JA, Bond DR. Shewanella secretes flavins that mediate extracellular electron transfer. Proc Natl Acad Sci U S A. 2008;105:3968-73.

21. Von Canstein H, Ogawa J, Shimizu S, Lloyd JR. Secretion of flavins by Shewanella species and their role in extracellular electron transfer. Appl Environ Microbiol. 2008;74:615-23.

22. Coursolle D, Baron DB, Bond DR, Gralnick JA. The Mtr respiratory pathway is essential for reducing flavins and electrodes in Shewanella oneidensis. J Bacteriol. 2010;192:467-74.

23. Mitchell AC, Peterson L, Reardon $C L$, Reed SB, Culley DE, Romine MR, et al. Role of outer membrane c-type cytochromes MtrC and OmcA in Shewanella oneidensis MR-1 cell production, accumulation, and detachment during respiration on hematite. Geobiology. 2012;10:355-70.

24. Saffarini DA, Schultz R, Beliaev A. Involvement of cyclic AMP (CAMP) and CAMP receptor protein in anaerobic respiration of Shewanella oneidensis. J Bacteriol. 2003;185:3668-71.

25. Charania MA, Brockman KL, Zhang Y, Banerjee A, Pinchuk GE, Fredrickson JK, et al. Involvement of a membrane-bound class III adenylate cyclase in regulation of anaerobic respiration in Shewanella oneidensis MR-1. J Bacteriol. 2009;191:4298-306.

26. Myers CR, Myers JM. Outer membrane cytochromes of Shewanella putrefaciens MR-1: spectral analysis, and purification of the $83-\mathrm{kDa}$ c-type cytochrome. Biochim Biophys Acta. 1997;1326:307-18.

27. Beliaev AS, Klingeman DM, Klappenbach JA, Wu L, Romine MF, Tiedje JM, et al. Global transcriptome analysis of Shewanella oneidensis MR-1 exposed to different terminal electron acceptors. J Bacteriol. 2005;187:7138-45.

28. Teal TK, Lies DP, Wold BJ, Newman DK. Spatiometabolic stratification of Shewanella oneidensis biofilms. Appl Environ Microbiol. 2006;72:7324-30.

29. Rosenbaum MA, Bar HY, Beg QK, Segrè D, Booth J, Cotta MA, et al. Transcriptional analysis of Shewanella oneidensis MR-1 with an electrode compared to Fe(III) citrate or oxygen as terminal electron acceptor. PLoS One. 2012;7:e30827.

30. Pirbadian S, Barchinger SE, Leung KM, Byun HS, Jangir Y, Bouhenni RA, et al. Shewanella oneidensis MR-1 nanowires are outer membrane and periplasmic extensions of the extracellular electron transport components. Proc Natl Acad Sci U S A. 2014;111:12883-8.

31. Beliaev AS, Saffarini DA, McLaughlin JL, Hunnicutt D. MtrC, an outer membrane decahaem c cytochrome required for metal reduction in Shewanella putrefaciens MR-1. Mol Microbiol. 2001;39:722-30.

32. Shao W, Price MN, Deutschbauer AM, Romine MF, Arkin AP. Conservation of transcription start sites within genes across a bacterial genus. mBio. 2014;5:e01398-14

33. Mitra A, Kesarwani AK, Pal D, Nagaraja V. WebGeSTer DB-a transcription terminator database. Nucleic Acids Res. 2011;39:D129-35.

34. Gao H, Wang X, Yang ZK, Chen J, Liang Y, Chen H, et al. Physiological roles of ArcA, Crp, and EtrA and their interactive control on aerobic and anaerobic respiration in Shewanella oneidensis. PLoS One. 2010;5:e15295.

35. Jansen C, Gronenborn AM, Clore GM. The binding of the cyclic AMP receptor protein to synthetic DNA sites containing permutations in the consensus sequence TGTGA. Biochem J. 1987;246:227-32.

36. Kolb A, Busby S, Buc H, Garges S, Adhya S. Transcriptional regulation by CAMP and its receptor protein. Annu Rev Biochem. 1993;62:749-95.

37. Hollands K, Busby SJW, Lloyd GS. New targets for the cyclic AMP receptor protein in the Escherichia coli K-12 genome. FEMS Microbiol Lett. 2007;274:89-94.

38. Wang H, Correa E, Dunn WB, Winder CL, Goodacre R, Lloyd JR. Metabolomic analyses show that electron donor and acceptor ratios control anaerobic electron transfer pathways in Shewanella oneidensis. Metabolomics. 2012;9:642-56.

39. Yanisch-Perron C, Vieira J, Messing J. Improved M13 phage cloning vectors and host strains: nucleotide sequences of the M13mp18 and pUC19 vectors. Gene. 1985;33:103-19.

40. Penfold RJ, Pemberton JM. An improved suicide vector for construction of chromosomal insertion mutations in bacteria. Gene. 1992;118:145-6.

41. Endoh T, Habe H, Yoshida T, Nojiri H, Omori T. A CysB-regulated and $\sigma^{54}$ dependent regulator, SfnR, is essential for dimethyl sulfone metabolism of Pseudomonas putida strain DS1. Microbiology. 2003;149:991-1000.

42. Brückner R, Titgemeyer F. Carbon catabolite repression in bacteria: choice of the carbon source and autoregulatory limitation of sugar utilization. FEMS Microbiol Lett. 2002;209:141-8.

43. Stülke J, Hillen W. Carbon catabolite repression in bacteria. Curr Opin Microbiol. 1999;2:195-201.

44. Murphy JN, Durbin KJ, Saltikov CW. Functional roles of arcA, etrA, cyclic AMP (CAMP)-CAMP receptor protein, and cya in the arsenate respiration pathway in Shewanella sp. strain ANA-3. J Bacteriol. 2009;191:1035-43.

45. Dong Y, Wang J, Fu H, Zhou G, Shi M, Gao H. A Crp-dependent two-component system regulates nitrate and nitrite respiration in Shewanella oneidensis. PLOS One. 2012;7:e51643.

46. Botsford JL, Harman JG. Cyclic AMP in prokaryotes. Microbiol Rev. 1992;56:100-22. 
47. Rhodius VA, West DM, Webster CL, Busby SJ, Savery NJ. Transcription activation at class II CRP-dependent promoters: the role of different activating regions. Nucleic Acids Res. 1997;25:326-32.

48. Busby S, Ebright RH. Transcription activation at class II CAP-dependent promoters. Mol Microbiol. 1997;23:853-9.

49. Joung JK, Le LU, Hochschild A. Synergistic activation of transcription by Escherichia coli cAMP receptor protein. Proc Natl Acad Sci U S A. 1993:90:3083-7.

50. Tebbutt J, Rhodius VA, Webster CL, Busby SJW. Architectural requirements for optimal activation by tandem CRP molecules at a class I CRP-dependent promoter. FEMS Microbiol Lett. 2002;210:55-60.

51. Raibaud O, Schwartz M. Positive control of transcription initiation in bacteria. Annu Rev Genet. 1984;18:173-206.

52. Unden G, Duchene A. On the role of cyclic AMP and the Fnr protein in Escherichia coli growing anaerobically. Arch Microbiol. 1987;147:195-200.

53. Green J, Paget MS. Bacterial redox sensors. Nat Rev Microbiol. 2004;2:954-66.

54. Kristensen HH, Valentin-Hansen P, Søgaard-Andersen L. Design of CytR regulated, CAMP-CRP dependent class II promoters in Escherichia coli: RNA polymerase-promoter interactions modulate the efficiency of CytR repression. J Mol Biol. 1997;266:866-76.

55. Valentin-Hansen P, Søgaard-Andersen L, Pedersen H. A flexible partnership: the CytR anti-activator and the CAMP-CRP activator protein, comrades in transcription control. Mol Microbiol. 1996;20:461-6.

56. McLeod SM, Johnson RC. Control of transcription by nucleoid proteins. Curr Opin Microbiol. 2001;4:152-9.

57. Mukerji M, Mahadevan S. Characterization of the negative elements involved in silencing the bgl operon of Escherichia coli: possible roles for DNA gyrase, H-NS, and CRP-CAMP in regulation. Mol Microbiol. 1997;24:617-27.

58. Germer J, Becker G, Metzner M, Hengge-Aronis R. Role of activator site position and a distal UP-element half-site for sigma factor selectivity at a CRP/H-NS-activated $\sigma^{\mathrm{s}}$-dependent promoter in Escherichia coli. Mol Microbiol. 2001;41:705-16.

59. Kouzuma A, Endoh T, Omori T, Nojiri H, Yamane H, Habe H. Transcription factors CysB and SfnR constitute the hierarchical regulatory system for the sulfate starvation response in Pseudomonas putida. J Bacteriol. 2008;190:4521-31.

60. Kouzuma A, Hashimoto K, Watanabe K. Roles of siderophore in manganese-oxide reduction by Shewanella oneidensis MR-1. FEMS Microbiol Lett. 2012:326:91-8.

61. Kouzuma A, Hashimoto K, Watanabe K. Influences of Aerobic respiration on current generation by Shewanella oneidensis MR-1 in single-chamber microbial fuel cells. Biosci Biotechnol Biochem. 2012;76:270-5.

62. Kouzuma A, Oba H, Tajima N, Hashimoto K, Watanabe K. Electrochemical selection and characterization of a high current-generating Shewanella oneidensis mutant with altered cell-surface morphology and biofilm-related gene expression. BMC Microbiol. 2014;14:190.

63. Newton GJ, Mori S, Nakamura R, Hashimoto K, Watanabe K. Analyses of current-generating mechanisms of Shewanella loihica PV-4 and Shewanella oneidensis MR-1 in microbial fuel cells. Appl Environ Microbiol. 2009;75:7674-81.

64. Saltikov CW, Newman DK. Genetic identification of a respiratory arsenate reductase. Proc Natl Acad Sci U S A. 2003;100:10983-8.

65. Kouzuma A, Meng X-Y, Kimura N, Hashimoto K, Watanabe K. Disruption of the putative cell surface polysaccharide biosynthesis gene SO3177 in Shewanella oneidensis MR-1 enhances adhesion to electrodes and current generation in microbial fuel cells. Appl Environ Microbiol. 2010;76:4151-7.

66. Choi KH, Kumar A, Schweizer HP. A 10-min method for preparation of highly electrocompetent Pseudomonas aeruginosa cells: application for DNA fragment transfer between chromosomes and plasmid transformation. J Microbiol Methods. 2006;64:391-7.

67. Miller JH. Experiments in molecular genetics. New York: Cold Spring Harbo Laboratory Press; 1972.

\section{Submit your next manuscript to BioMed Central and take full advantage of:}

- Convenient online submission

- Thorough peer review

- No space constraints or color figure charges

- Immediate publication on acceptance

- Inclusion in PubMed, CAS, Scopus and Google Scholar

- Research which is freely available for redistribution

Submit your manuscript at www.biomedcentral.com/submit 